\title{
Rootstock-scion interactions of selected Annona species
}

\author{
H.M.S. Heenkenda*, B.L. Gunathilaka and J.P. Iswara \\ 1 Horticultural Crops Research and Development Institute, Department of Agriculture, Gannoruwa, Peradeniya. \\ 2 In-Service Training Institute, Department of Agriculture, Mahailuppallama. \\ 3 Department of Crop Science, Faculty of Agriculture, University of Peradeniya, Peradeniya.
}

Revised: 11 August 2008 ; Accepted: 02 October 2008

\begin{abstract}
Annona species are commonly grown in home gardens of Sri Lanka. The nutritive value of Annona fruits and their value in the fruit processing sector have been realized recently. This has increased the demand for planting material. Use of seedlings as planting material generally resulted in extended vegetative growth, low productivity, inferior fruit quality and inconsistency in yield and quality. Vegetatively propagated plants of superior varieties will solve some of these problems. This study was therefore undertaken at the Horticultural Research and Development Institute, Gannoruwa during Maha season 2006/2007, to identify suitable rootstock species for some selected promising Annona accessions. Soursop (Annona muricata L.), cherimoya (A. cherimola Mill) and atemoya (A. squamosa $\times$ A. cherimola) scion varieties were grafted on to soursop, cherimoya and sweetsop (A. squamosa L.) rootstocks. The experimental design was based on two factor factorial set in Completely Randomized Design with three replications, with 15 plants in each treatment. Percentage success in grafting was much less than the percentage bud take-on showing need for improvement of grafting. Atemoya and soursop were successfully grafted on to cherimoya rootstock (83.3 and $73.3 \%$ respectively). Soursop scion grafted on to any one of the rootstock species showed the least successful combination (33\%). The scion growth, indicated as length of the first shoot and leaf production (number of leaves/graft/week), depended on the rootstock- scion combination.
\end{abstract}

Keywords: Annona, grafting, interaction, rootstock species, scion.

\section{INTRODUCTION}

The genus Annona (Annonaceae) includes more than 50 species widely distributed in different agro-ecological regions of Sri Lanka. Some of them are cultivated for their edible fruits while others are cultivated for ornamental purposes or to produce perfumes. Thus, they are multipurpose trees. The fruits, rich in energy, vitamin $\mathrm{C}$ and minerals such as calcium, phosphorous and potassium, are consumed either fresh or processed ${ }^{1}$. There is a potential for this fruit in the food processing industry. Annona fruit, seed and many parts of the tree are used in traditional medicine. The green fruit and seeds have effective vermicidal and insecticidal properties ${ }^{2}$. The potential of Annona species to produce nutritive fruits indicates the need for research on varietal improvement, production of high quality planting material, large scale cultivation and value addition.

Soursop (A. muricata L.), cherimoya (A. cherimola Mill), custard apple $(A$. reticulata L.), and sweetsop (A. squamosa L.) species of Annona are abundant in home gardens in all agro-ecological regions of Sri Lanka ${ }^{3}$. Atemoya (Annona squamosa $\times$ A. cherimola) has been introduced to the island from Australia under the FAO/UNDP/SRL Horticultural Project during the 1983-1988 period. Annona is cultivated under a wide range of ecological conditions with a minimum effort. Annona fruit is available in many months of the year and is consumed as fresh fruit or as juice. Small and medium scale fruit processing enterprises offer a market for these fruits. However, unavailability of quality fruits in large quantities regularly is a common problem for development of the Annona industry in the island.

High quality planting material should be made available in line with expansion of cultivation of Annona. This can be achieved by selection of suitable rootstock species to increase the efficiency of vegetative propagation techniques. Seedlings of Annona spp. take about five to six years from planting to attain the first flowering stage while the grafts take about two and half years. The present study was undertaken to investigate the interaction between common Annona species as 
rootstocks and scions, to identify the most effective rootstock-scion combinations for different species and to make use of conventional wedge grafting efficiently.

\section{METHODS AND MATERIALS}

This study was conducted at the Horticultural Research and Development Institute (HORDI), Gannoruwa, $\left(\mathrm{WM}_{2 \mathrm{~b}}\right.$ agro-ecological region) during November 2006February 2007. The scion wood species of soursop, cherimoya (C-1: a local selection) and atemoya (var. African Pride) were grafted on to the rootstock species of soursop, cherimoya (C-1: local selection) and sweetsop, employing the conventional wedge grafting technique. The experiment was laid in Completely Randomized Design with three replications and 15 plants (sub samples) per treatment per replicate. Approximately 10-11 month old seedlings of uniform size were selected as rootstocks. The scion wood, about $15 \mathrm{~cm}$ long, was extracted from 10 year old fruiting trees of each species grown in the orchard of the HORDI, Gannoruwa. The fresh grafts were maintained under $70 \%$ shade during the study period of $10 \mathrm{wks}$. The bud take-on indicates the possible fusing of scion and rootstock. Percentage bud take-on (successful healing of the graft union), successful grafts (successfully established grafts with the scion grown up to $30-35 \mathrm{~cm}$ in height), number of days taken for bud break after grafting, length of the first shoots emerging from the grafts, number of leaves produced on the first shoots, position of the first shoot on the graft, total number of shoots emerging per graft and total number of leaves produced per graft were recorded during the period of 10 wks after grafting.

\section{RESULTS AND DISCUSSION}

There was a considerable effect of rootstock species and scion species on the percentage bud take-on in the grafts (Figures 1 and 2). The highest percentage bud take-on was recorded for atemoya grafted on to soursop rootstock $(90 \%)$, cherimoya grafted on to cherimoya rootstock $(90 \%)$ and atemoya grafted on to cherimoya rootstock $(86.7 \%)$ showing no significant difference among them in this respect. The lowest bud take-on was recorded for soursop grafted on to its own rootstock and on to sweetsop rootstock (40\%). Grafting cherimoya on to soursop and sweetsop rootstocks resulted in moderate percentage value of bud take-on (73.3\%) while cherimoya rootstock for soursop grafting was less effective (66.7\%).

The percentage of successful grafts was lower than the percentage bud take-on showing the need for improvement in grafting (Figures 1 and 2). However, the highest percentage of successful grafts was achieved when atemoya was grafted on to cherimoya rootstock $(83.3 \%)$. When the same scion species was grafted on to sweetsop rootstock, the percentage of successful grafts achieved was $73.3 \%$ with a significant difference between them. The lowest percentage of successful grafts was recorded for the soursop grafted on to its own rootstock and on to sweetsop rootstock (36.7\% and 33.3\% respectively). Soursop was more successful when grafted on to cherimoya rootstock (66.7\%). All other rootstockscion combinations resulted in moderate percentages of successful grafts (60-66.7\%). Thus, cherimoya was the most suitable rootstock for both atemoya and soursop. Soursop was the most suitable rootstock for cherimoya in terms of percentage successful grafts (Figure 1). Cherimoya is used as a rootstock for atemoya in Israel ${ }^{4}$. Soursop grafted on sweetsop rootstocks does not last long, which could be due to incompatibility ${ }^{5}$.

There was no effect of rootstock on the time taken for bud break (Figure 3). However, earliest bud break was observed in the soursop and atemoya grafts (15.5 days after grafting) on cherimoya rootstock. Cherimoya grafts on soursop rootstock took the longest time for bud break (20 days). The time taken for bud break depends mostly on the condition of the scion. The first shoot in all grafts of the present experiment emerged three weeks after grafting.

There was a difference in the length of the first shoot in different rootstock-scion combinations (Figure 4). Since the interaction between scion and rootstock is significant, the scion growth is determined by the rootstock. Hence, suitable rootstock species should be selected for the grafting of each scion species. The maximum length of the first shoot was recorded for cherimoya grafted on to soursop rootstock $(8.2 \mathrm{~cm})$ and cherimoya rootstock $(6.2$ $\mathrm{cm})$. The length difference between them showed the most suitable combinations for early emergence of scion. Shoots emerging from atemoya grafted on to soursop rootstock showed the least growth during the same period $(2.0 \mathrm{~cm})$.

The increase in shoot length of all combinations were below $0.8 \mathrm{~cm} /$ week at five weeks after grafting (Figure 4). Cherimoya grafted on to soursop and soursop grafted on to sweetsop showed relatively higher growth $(1.1 \mathrm{~cm} /$ week) at the beginning of this period and the shoot extension was less in other combinations. The highest rate of growth of the first shoot during the $7^{\text {th }}$ and $9^{\text {th }}$ week was recorded for cherimoya grafted on to cherimoya and soursop rootstocks, and soursop scion on to sweetsop rootstocks. This showed that the characteristics of the graft were influenced by both the stock and the scion. The rootstocks influenced the growth habit, flowering and yielding capacity of the graft ${ }^{6}$. 

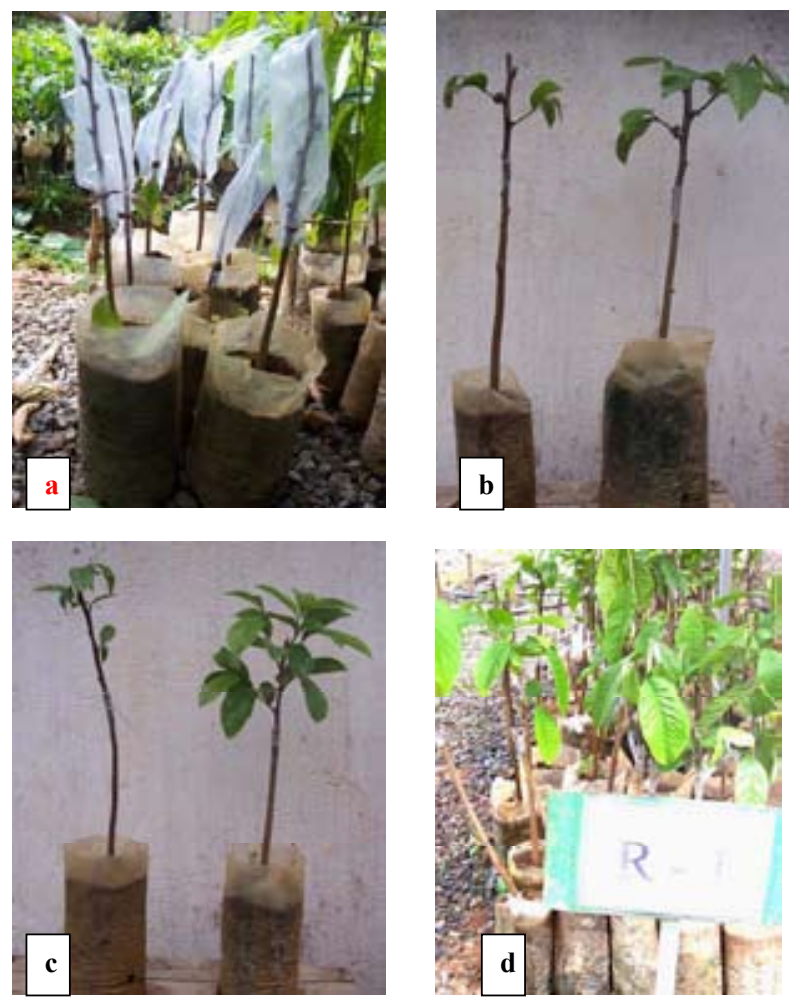

Figure 1: Grafts of Annona species: a) fresh grafts in single propagators; b) cherimoya grafted on to soursop rootstock; c) soursop grafted on to cherimoya rootstock; d) atemoya grafted on to cherimoya rootstock

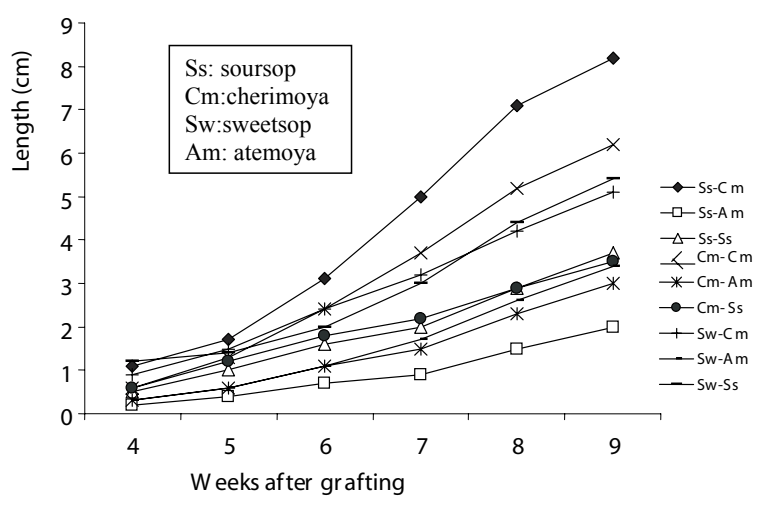

Figure 4: Length of the first shoots emerged from the grafts

The mean number of leaves produced on the first shoot of the grafts was influenced by the relationship between rootstock and scion species (Figure 5). The highest number of leaves on the first shoot was recorded in cherimoya on soursop rootstock and on its own rootstock (7.7 leaves). Soursop grafted on to cherimoya rootstock and sweetsop rootstock also showed vigorous growth as indicated by the second highest number of leaves on the

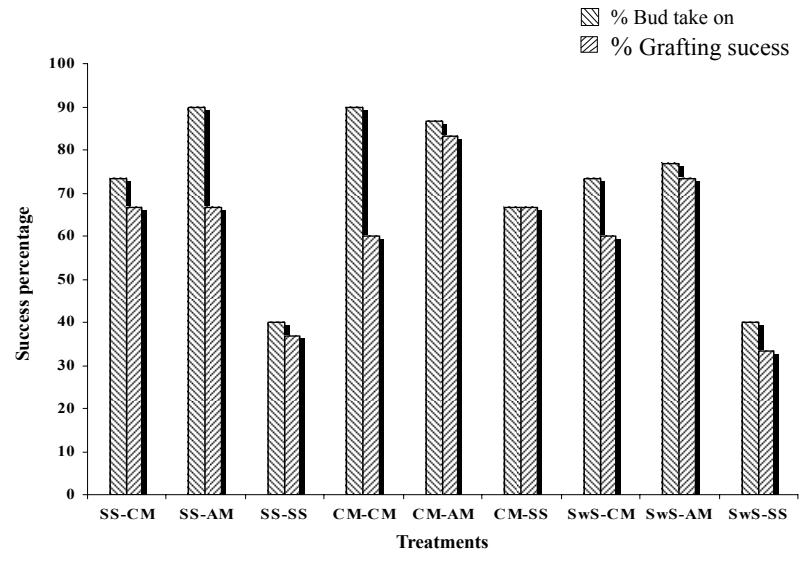

Figure 2: Percentage of bud take-on and grafting success

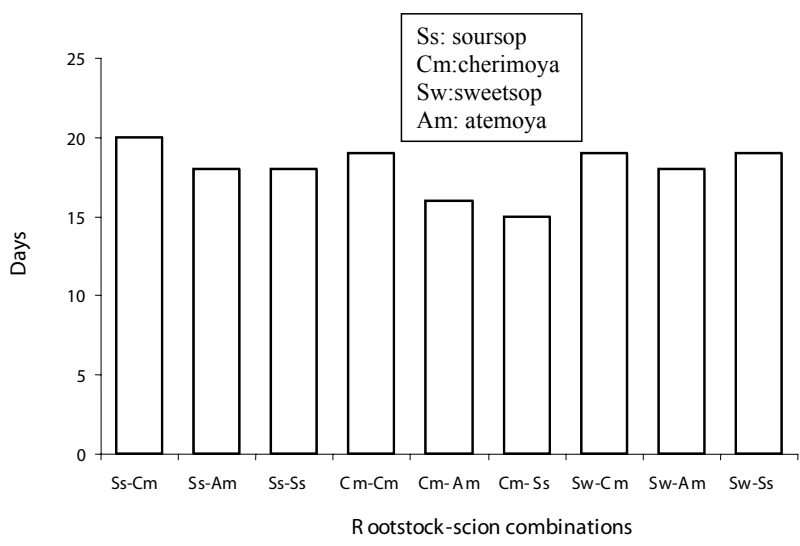

Figure 3: Days taken for bud break after grafting

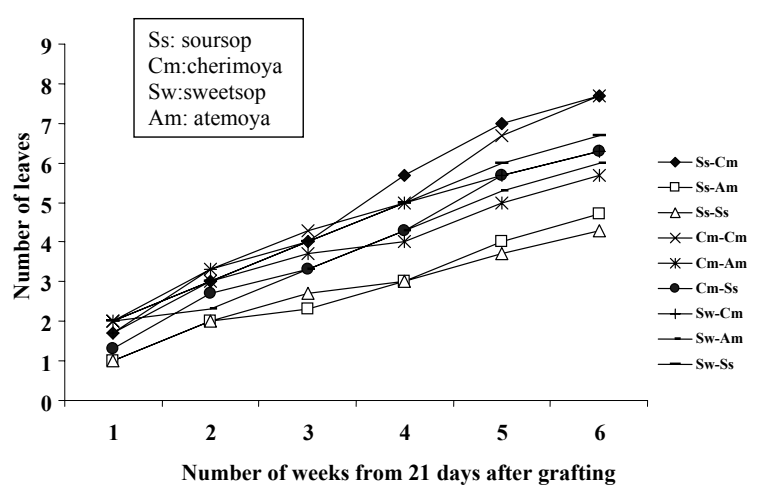

Figure 5: Number of leaves of the first shoot on scion

first shoot (6.3-6.7 leaves). The least number of leaves on the first shoot was recorded in the atemoya and soursop grafts made on soursop rootstocks (4.7 leaves). Though cherimoya scion grows vigorously on all rootstock species tested, cherimoya rootstock was more suitable for atemoya. Sweetsop rootstock was more suitable for soursop, in terms of the number of leaves produced in the first shoot of the graft. 


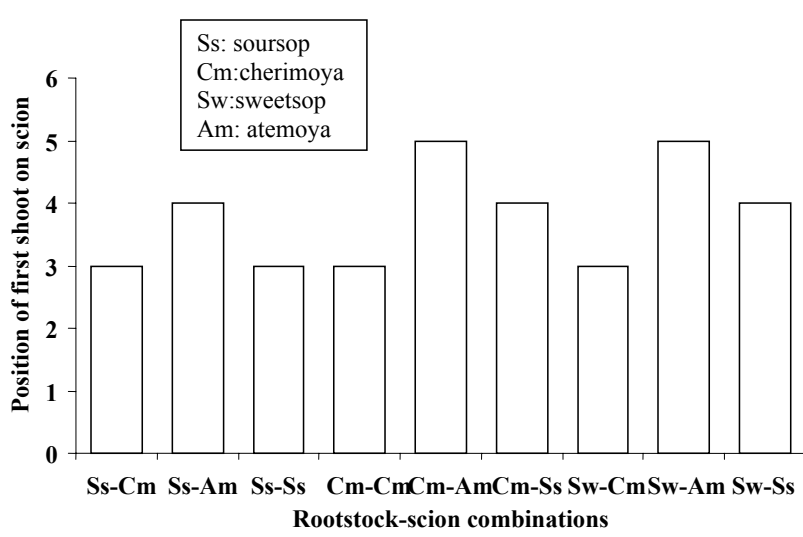

Figure 6: Position of the first shoot of the grafts

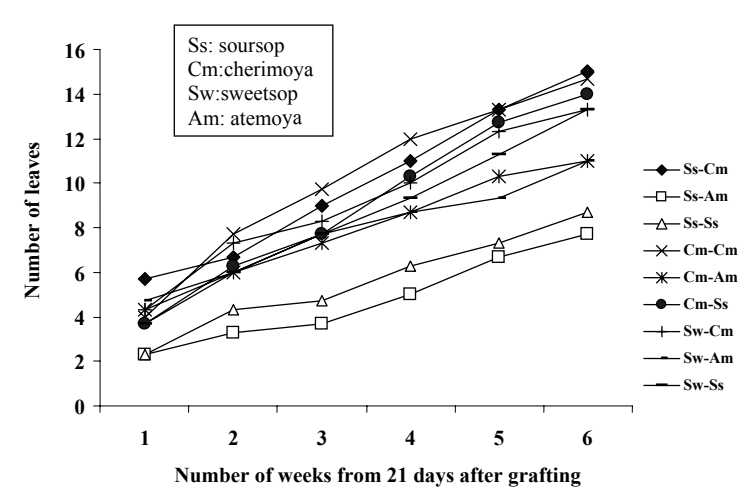

Figure 8: Total number of leaves on the scion

The rate of leaf emergence on the first shoot of the grafts was below one leaf /week until the $6^{\text {th }}$ week after grafting but increased thereafter (Figure 5). The first shoot of the cherimoya graft made on soursop and cherimoya rootstocks showed a higher leaf emergence rate throughout the period. Soursop and atemoya grafted on to sweetsop rootstock also showed a similar rate of leaf emergence.

The sequence of the shoots emerging from the graft indicates the future shape and architecture of the tree and the total number of shoots that continue to grow. The position of the first shoot (number of nodes away from graft union) also influences the position and growth of the subsequent shoots and thereby the framework of the tree. The position of the first shoot was not significantly affected by rootstock species (Figure 6). However, the position of this shoot seemed to vary according to the scion species. Almost all the first shoots emerged at $3^{\text {rd }}, 4^{\text {th }}$ or $5^{\text {th }}$ node of the scion wood but most atemoya grafts produced the first shoot at the $5^{\text {th }}$ node. In most of soursop grafts, the first shoot was produced at about 3 nodes above the graft union. The emergence of first shoot may depend on the development of axillary buds

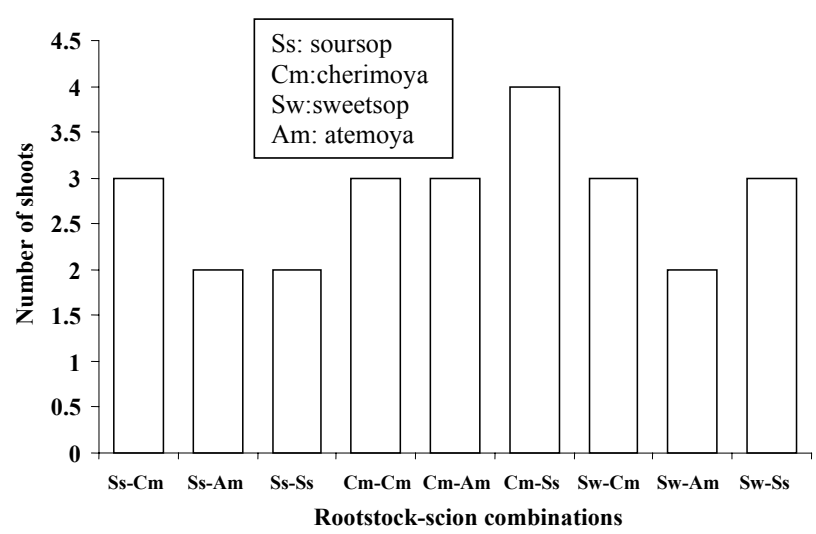

Figure 7: Total number of shoots emerged per graft

and the sequence of their maturity influenced by the scion species. This suggests the importance of selection of suitable lengths of the scion wood of different Annona species for grafting.

The total number of shoots per scion did not vary significantly. The highest number of shoots (four shoots/ scion) emerged from soursop scions grafted on to cherimoya rootstock. Three shoots emerged on cherimoya grafted on to soursop rootstock, cherimoya grafted on to cherimoya rootstock, atemoya grafted on to cherimoya rootstock and soursop grafted on to sweetsop rootstock (Figure 7). This could be attributed to the status of the scion wood, mostly the length and number of nodes (number of mature axillary buds) present on the scion.

The total number of leaves produced on a graft varied among different rootstock-scion combinations showing the effect of interaction between the rootstock and scion on leaf production (Figure 8). Cherimoya grafts made on soursop and cherimoya rootstocks produced the highest number of leaves of 15 . This shows that cherimoya on soursop and cherimoya rootstocks are compatible combinations for vigorous growth of cherimoya scions. However, atemoya grafted on to soursop rootstock produced the least number of leaves (7.7 leaves) and soursop grafted on to its own rootstock had a slightly higher number of leaves per graft (8.7 leaves) indicating that these combinations are not suitable to develop a strong canopy.

The highest rate of leaf emergence in the grafts was recorded in the $4^{\text {th }}$ week after grafting (2.2 leaves/ week) (Figure 5). Thereafter, this rate was maintained at a slightly lower level (1.4 - 1.7 leaves / week) but declined in the $9^{\text {th }}$ week after grafting. This could be due to maturity of the emerged leaves. Cherimoya grafted on cherimoya and soursop grafted on cherimoya rootstock achieved higher rates of leaf emergence in most weeks, 
though their total leaf production was slightly less than that of cherimoya grafted on to soursop rootstock. The lowest rate of leaf emergence was continually recorded for atemoya grafted on to soursop rootstock.

\section{CONCLUSION}

Suitable rootstocks should be selected to graft different Annona species. Scion species on its own rootstock is not the best combination. Length of the scion of each species determined the growth of the first bud as indicated by the position of the first shoot emerging from the scion. Cherimoya was the most suitable rootstock for atemoya and soursop scions, when grafted using the wedge grafting technique. Soursop was the most suitable rootstock for cherimoya. These grafts established well and grew faster resulting in a dense canopy during the first nine weeks after grafting. Other Annona spp. not included into this study, should also be tested in reciprocal combinations in future.

\section{References}

1. Anonymous (2002). Fruits for the future. Fact sheet number 05, International Centre for Underutilized Crops, University of Southampton, U.K.

2. Rayes F.R. \& Santos A.C. (1931). The isolation of annonaine from Annona squamosa L. Philippine Agriculturist 26 (5): 425-445.

3. Anonymous (2005). Exploration. collection, conservation and characterization of underutilized fruits. HORDI Annual Report, Horticultural Research and Development Institute, Gannoruwa, Peradeniya.

4. Morton J. (1987). Atemoya. In: Fruits of Warm Climates. (Ed. F.J. Morton). pp.72-75. Creative Resource Systems, Inc., Winterville N.C. 28590, Miami, Florida, U S A.

5. Morton J. (1987). Cherimoya. In: Fruits of Warm Climates. (Ed. F.J. Morton). pp. 65-69. Creative Resource System Inc., Winterville, N.C. 28590, Miami, Florida, U S A.

6. Nanda K.K. \& Kochhar V.K. (1995). Vegetative Propagation of Plants. Kalyani Publishers, New Delhi, India. 